\title{
The analysis of relationship between experiential marketing, service quality, visitors' satisfaction, and revisit intention: study on tourism industry
}

\author{
Adinda Sekar Ramdhani ${ }^{1}$ and Sri Rahayu Tri Astuti ${ }^{2}$ \\ 1,2Department of Management, Faculty of Economics and Business, Universitas Diponegoro, Indonesia
}

\begin{tabular}{ll}
\hline Abstract & This study aims to analyze the impact of experiential marketing and service quality on revisit \\
intention which visitors' satisfaction as mediating variable. The sample of our study was the \\
135 visitors' of Grand Puri Maerokoco, one of the tourism sites in Semarang, Central Java, \\
Indonesia. The result of SEM analysis on those data shows that experiential marketing and \\
service quality have indirect, positive, and significant effect on revisit intention, using \\
visitors' satisfaction as intervening variable. However, experiential marketing and service \\
quality are not significantly affected revisit intention. Discussions and implications of this \\
study are presented.
\end{tabular}

\section{INTRODUCTION}

Recently, governments commitment in developing their tourism industry has been increased almost in every country since its multiplier effect on the states economic growth. In line with the governments' growing attention on tourism industry, scholars interest in studying the industry has been increased as well.

Among several topics, Shoemaker and Lewis (1999) saw that in economy perspective, the study of revisit intention is considered as one of the most important aspects for tourism industry to operate effectively and efficiently, because it discuss how to attract the interest of the visitors who have ever been there previously, thus this will be saving cost more than trying to attract new visitors. While the interest to revisit will happen if the visitor is satisfied with the visit previously done.

Along with the development of revisit intention studies, some constructs have become prominent determinants examined. Some of those constructs were experiential marketing (see: Shahijan, Rezei, \& Amin, 2018; Hyunjin, 2013) and service quality (see: Raza, Siddiquei, Awan, \& Bukhari, 2012; Amin \& Nasharuddin, 2013).

However, studies linking experiential marketing on revisit intention as well as service quality on revisit intention suggested inconsistencies. Some studies found that experiential marketing has significant effect on revisit intention; but another studies found the opposite result. Similar results also found in studies examining the effect of service quality on revisit intention.

Those inconsistent results shows that there could be another mechanism of how experiential marketing and service quality affecting tourists' revisit intention. Therefore, our study attempted to fill this gap by proposing visitors satisfaction as intermediary of both variables and revisit intention.

\section{LITERATURE REVIEW AND HYPOTHESES DEVELOPMENT}

\section{The effect of experiential marketing on visitors' satisfaction}

Research conducted by Wu \& Liang (2009) showed that the value of experience gained by the restaurant visitors affected visitors' satisfaction directly and positively. In other research by Yeh \& Chen (2019) also proved that experiential Marketing had positive and significant effect on visitors' satisfaction in tourism industry in Taiwan. Supports also provided by Shahijan et al. (2018) who examined the marketing strategy on cruise ship tour, showing that there is significant effect between experience on visitor satisfaction.

From the above explanation thus the hypotheses is formulated as follow: 
H1: Experiential marketing has positive effect on visitors' satisfaction

\section{The effect of experiential marketing on revisit intention}

Shahijan et al. (2018) in his research explained that experiential marketing in cruise tourism in Malaysia had positive and significant effect on the revisit intention of the customers. A study by Wulanjani \& Derriawan (2017) in Taman Kencana Bogor Restaurant also concluded that experiential based marketing affected revisit intention positively and significantly. Then other research by Hyunjin (2013) about revisit intention at franchised beauty confirmed the same results.

From the above explanation thus the hypotheses is formulated as follow:

H2: Experiential marketing has positive effect on revisit intention

\section{The effect of service quality on visitors'}

In the research done by Wu (2011) using hospital patients as the respondentts, it was stated that service quality at the hospital affected patient satisfaction positively and significantly. In another research conducted by Wu et al. (2015) it is found that service quality affected positively and significantly on visitor satisfaction at hot water bath in China. The argument that service quality has positive and significant effect on satisfaction is also corroborated by Ismail, Hanafiah, Aminuddin, \& Mustafa (2016) about the home stay service based on community.

From the above explanation thus the hypotheses is formulated as follow:

H3: Service quality has positive effect on visitors' satisfaction

\section{The effect of service quality on revisit intention}

Timur (2019) in the research about thermal tourism, stated that there is positive and

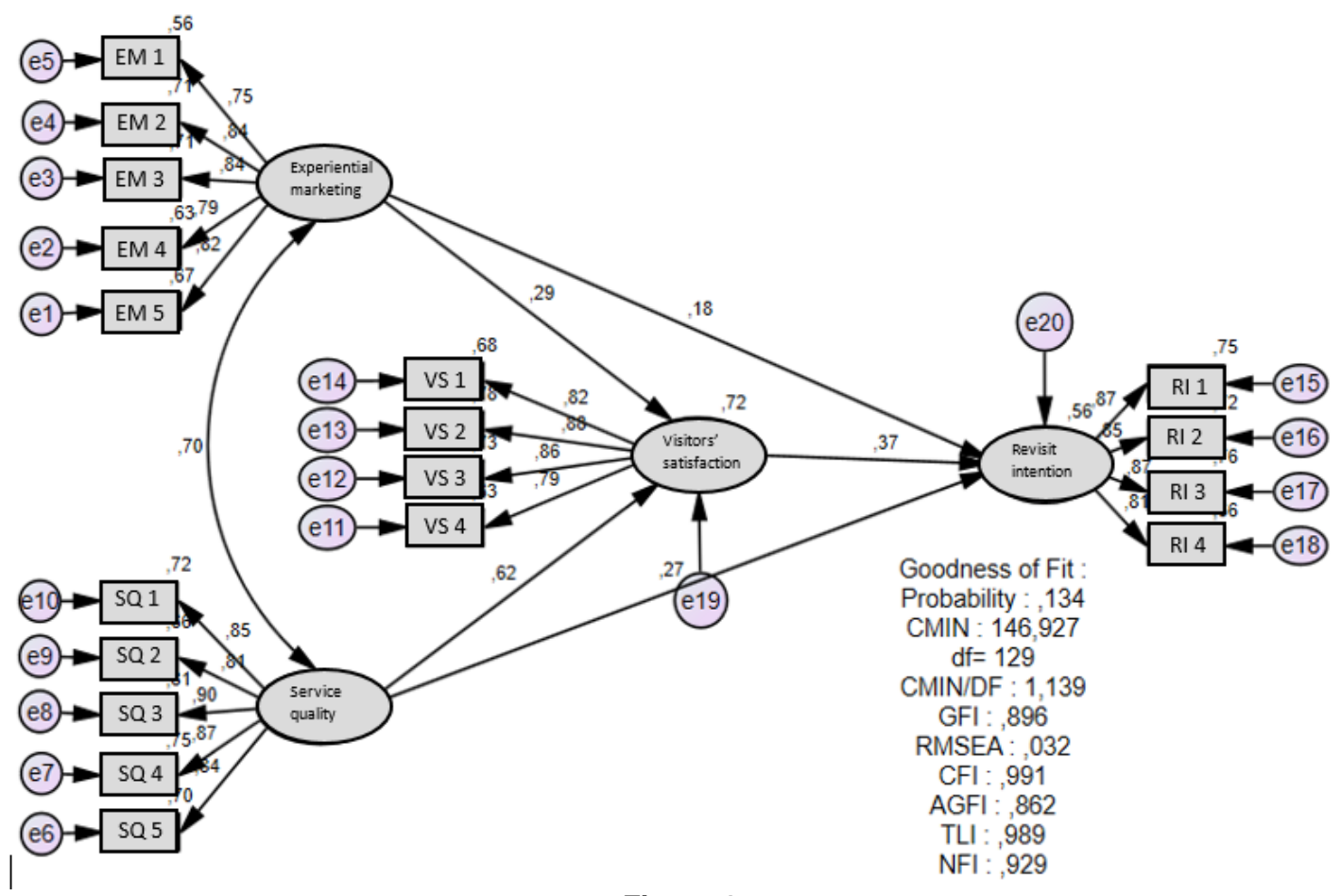

Figure 1.

The confirmatory analysis of full structural model

satisfaction 
that service quality at D'Cost restaurant in Malang city affected revisit intention positively on its customers'. Identic result was reported by Raza et al. (2012) stated that service quality has positive effect on revisit intention of the visitors of a Hotel in Pakistan.

From the above explanation thus the hypotheses is formulated as follow:

H4: Service Quality has positive effect on Revisit intention

\section{The effect of visitor satisfaction on revisit intention}

Studies conducted by Wu et al. (2015) about revisit intention in hot water bath industry in China, Thiumsak \& Ruangkanjanases (2016) about revisit intention in Bangkok, Thailand, and Woojin (2017) about revisit intention at food and wine festival showed that there was positive and significant effect of visitors' satisfaction on revisit intention to the same tourism spot or city in the future.

From the above explanation thus the hypotheses is formulated as follow:

H5: Visitors' satisfaction has positive effect on revisit intention

\section{METHODS}

The population set in this research is the people who have visited Grand Puri Maerokoco. Sample used in this research was 135 respondents. $53 \%$ of the respondents were male, while the rest were female. Majoruty of these respondents were 17-25 years old (90\%), and their current status were a students (66\%). $43 \%$ of the respondents admitted that they just once visit the place; while the rest of them (57\%) admitted that they had visited more than twice. These data then analyzed using AMOS 23 program. SEM is an analysis tool which is a combination from measurement model analyzing the relationship of each indicator on its variable and structural model analyzing the relationship between variables.

To measure experiential marketing, we use the scale developed by Schmitt (1999) with 5 items. 5 items statements developed by Parasuraman, Zeithaml, \& Berry (1985) was used to measure service quality. In order to measure visitors' satisfaction, we used 4 items-questionnaire developed by Picón, Castro, \& Roldán (2014), while in order to measure revisit intention, we used scale developed by Ferdinand (2006) with 4 items.

\section{RESULTS AND DISCUSSION}

Hypothesis proposed was tested by observing critical ratio value and significant level of $P$ value, in which hypothesis would be accepted if $C . R$ value $\geq 1,96$ and $P \leq 0,05$. Based on Table 1, the results of hypothesis testing from the research model which has been formulated are as follow:

\section{The effect of experiential marketing on visitors' satisfaction}

Based on the testing result, the variable of experiential marketing has positive effect on visitors' satisfaction with critical ratio value of $3,107>1,96$ and significance with probability $0,002<0,05$. Thus it can be concluded that hypothesis 1 is supported. This finding in line with study coducted by Wu \& Liang (2009) and

Table 1.

Regression weight structural equational

\begin{tabular}{|c|c|c|c|c|c|c|c|}
\hline & & & Estimate & S.E. & C.R. & $\mathbf{P}$ & Label \\
\hline $\begin{array}{l}\text { Visitors' } \\
\text { satisfaction }\end{array}$ & $<---$ & $\begin{array}{l}\text { Experiantial } \\
\text { marketing }\end{array}$ & ,270 & ,087 & 3,107 & ,002 & Par_18 \\
\hline $\begin{array}{l}\text { Visitors' } \\
\text { satisfaction }\end{array}$ & $<--$ & Service quality &, 561 & ,090 & 6,204 & $* * *$ & Par_19 \\
\hline Revisit intention & $<--$ & $\begin{array}{l}\text { Visitors' } \\
\text { satisfaction }\end{array}$ & ,450 & , 189 & 2,379 &, 017 & Par_13 \\
\hline Revisit intention & $<--$ & $\begin{array}{l}\text { Experiantial } \\
\text { marketing }\end{array}$ & ,212 & ,130 & 1,637 & ,102 & Par_16 \\
\hline Revisit intention & $<---$ & Service quality & ,294 & ,158 & 1,861 &, 063 & Par_17 \\
\hline
\end{tabular}


Yeh \& Chen (2019). Our finding also supported by Shahijan et al. (2018) which found that there was significant effect between experience on visitor satisfaction.

\section{The effect of experiential marketing on revisit intention}

Based on the testing results, experiential marketing variabel affects revisit intention, with critical ratio value of 1,637 $<1,96$ but it has significance with probability value $0,102>$ 0,050 . Therefore it can be concluded that hypothesis 2 is not supported. This result is not consistent with study by Shahijan et al. (2018), Wulanjani (2017), and Hyunjin (2013). However, in another perspective it could be understood that there is an urgency to reveal another mechanism of how is the relationship between experiential marketing and revisit intention. The analysis results of hypothesis 1 and 5 provides an explanation how this mechanism is.

\section{The effect of service quality on visitors' satisfaction}

Based on the test result, the variable of service quality has positive effect on revisit intention, with critical ratio value 6,204 >1,96 and significance with probability ${ }^{* *}<0,05$. Therefore it can be concluded that hypothesis 3 is supported. This finding give additional support for some of previous studies ( $\mathrm{Wu}$, 2011; Wu et al., 2015; and Ismail et al., 2016)

\section{The effect of service quality on revisit intention}

Based on the test result, quality variable affects revisit intention, with critical ratio value $1,861<1,96$ but it has significance with probability value of $0,063>0,05$. Therefore it could be concluded that hypothesis 4 is not supported. However, in another perspective it could be understood that there is an urgency to reveal another mechanism of how is the relationship between service quality and revisit intention. The analysis results of hypothesis 3 and 5 provides an explanation how this mechanism is.

\section{The effect of visitors' satisfaction on revisit intention}

Based on the test result, Visitor Satisfaction variable affects positively on Revisit intention, with critical ratio value $2,379>1,96$ and the significance with probability value $0,017<$ 0,05 . Therefore it can be concluded that hypothesis 5 is supported.

\section{CONCLUSION}

The main objective of this paper is to reveal the mechanism of how experiential marketing and service quality affects revisit intention. The results as discussed in previous section show that our proposed variable, visitors' satisfaction may take a role as intermediary between both of the variables and revisit intention.

For managers of tourism sites, our study may give more comprehensive knowledge to increase revisit intention. Managers should not only focus on develop the quality of experiential marketing and service quality, but also focus on ensure that every tourists have high satisfaction on the tourism sites. To do so, they should ensure that visitors needs and expectation are fulfilled. They also should ensure that every visitors get good service and have a positive value. For researchers, our findings succesfully fill gap of inconsistecies in previous studies examining the effect of experiential marketing and service quality on revisit intention.

However, our study also still have limitations. First, our study only examine using path analysis. To provide more robust finding, future studies may use mediation or moderation analysis to uncover the mechanism between experiential marketing, service quality, and revisit intention. Second, because of limited time, our study only use cross section data. We suggest next studies to use another method such as longitudinal, qualitative, or experiment studies.

\section{REFERENCES}

Amin, M., \& Nasharuddin, S. Z. (2011). Hospital service quality and its effects on patient satisfaction and behavioural intention. https://doi.org/10.1108/CGIJ-05-20120016

Anwar, L. A., Suharyono, S., \& Bafadhal, A. S. (2018). Pengaruh dining service quality (dineserv) terhadap customer satisfaction dan revisit intention (survei pada pelanggan D'COST Seafood Restaurant Malang Town Square). Jurnal Administrasi Bisnis, 58(1), 27-35.

Ferdinand, A. (2006). Metode Penelitian Manajemen: Pedoman Penelitian untuk 
Penulisan Skripsi, Tesis, dan Disertasi IImu Manajemen. Semarang: Badan Penerbit Universitas Diponegoro.

Husain, U. (2005). Manajemen Riset dan Perilaku Konsumen. Jakarta: PT. Gramedia Pusat.

Hyunjin, J. (2013). The Effect of Experiential Marketing on Customer Satisfaction and Revisit Intention of Beauty Salon Franchise Stores. 17(3), 109-121.

Isa, S. M., Sze, G., Lim, S., \& Chin, P. N. (2019). Patients 'intent to revisit with trust as the mediating role: lessons from Penang Malaysia. https://doi.org/10.1108/IJPHM10-2017-0056

Ismail, M. N. I., Hanafiah, M. H., Aminuddin, N., \& Mustafa, N. (2016). Community-based Homestay Service Quality, Visitor Satisfaction, and Behavioral Intention. Procedia - Social and Behavioral Sciences, 222, 398-405. https://doi.org/10.1016/j.sbspro.2016.05.1 92

Parasuraman, A., Zeithaml, V. A., \& Berry, L. L. (1985). A Conceptual Model of Service Quality and Its Implications for Future Research. Journal of Marketing, 49(4), 41. https://doi.org/10.2307/1251430

Picón, A., Castro, I., \& Roldán, J. L. (2014). The relationship between satisfaction and loyalty: A mediator analysis. Journal of Business Research, 67(5), 746-751. https://doi.org/10.1016/j.jbusres.2013.11. 038

Raza, M. A., Siddiquei, A. N., Awan, H. M., \& Bukhari, K. (2012). Relationship between service quality, perceived value, satisfaction and revisit intention in hotel industry. Interdisciplinary journal of contemporary research in business, 4(8), 788-805.

Shoemaker, S., \& Lewis, R. C. (1999). Customer loyalty: the future of hospitality marketing. International journal of hospitality management, 18(4), 345-370.

Schmitt, B. (1999). Jurnal Manajemen Pemasaran Pemasaran Experiential Marketing. 3741.

Shahijan, M. K., Rezaei, S., \& Amin, M. (2018). Qualities of effective cruise marketing strategy: Cruisers' experience, service convenience, values, satisfaction and revisit intention. International Journal of Quality and Reliability Management, 35(10), 2304-2327. https://doi.org/10.1108/IJQRM-07-2017-
0135

Suyanto, M. (2007). Marketing Strategi Top Brand Indonesia. Yogyakarta: CV. Andi Offset.

Thiumsak, T., \& Ruangkanjanases, A. (2016). Factors Influencing International Visitors to Revisit. Journal of Economics, Business and Management, 4(3). https://doi.org/10.7763/JOEBM.2016.V4.3 94

Timur, B. (2019). Service Quality, Destination Image and Revisit Intention Relationships at Thermal Tourism Businesses. (January). https://doi.org/10.33083/0.2018.3

Woojin, L. (2017). The effects of festival attendees' experiential values and satisfaction on revisit intention to the destination; the case of a food and wine festival. International Journal of Contemporary Hospitality Management, 29(3). https://doi.org/http://dx.doi.org/10.1108/M RR-09-2015-0216

Wu, C.-C. (2011). The Impact Of Hospital Brand Image On Service Quality, Patient Satisfaction And Loyalty. African Journal of Business Management, 5(12), 48734882. https://doi.org/10.5897/AJBM10.1347

Wu, C. H. J., \& Liang, R. Da. (2009). Effect of experiential value on customer satisfaction with service encounters in luxury-hotel restaurants. International Journal of Hospitality Management, 28(4), 586-593. https://doi.org/10.1016/j.ijhm.2009.03.008

Wu, H. C., Ai, C. H., Yang, L. J., \& Li, T. (2015). A Study of Revisit Intentions, Customer Satisfaction, Corporate Image, Emotions and Service Quality in the Hot Spring Industry. Journal of China Tourism Research, 11(4), 371-401. https://doi.org/10.1080/19388160.2015.11 10545

Wulanjani, H., \& Derriawan, D. (2017). Dampak Utilitarian Value Dan Experiential Marketing Terhadap Customer Satisfaction Dan Revisit Intention. Jurnal Riset Manajemen dan Bisnis (JRMB) Fakultas Ekonomi UNIAT, 2(2), 121-130.

Yeh, T., \& Chen, S. (2019). The Relationships among Experiential Marketing, Service Innovation , and Customer Satisfaction A Case Study of Tourism Factories in Taiwan. 1-12. https://doi.org/10.3390/su11041041 